\title{
Activity of the Recommended and Optimized Rates of Pyridate on Chickpea - Mesorbizobium mediterraneum Symbiosis
}

\author{
Mehdi PARSA, Akbar ALIVERDI*, Hossein HAMMAMI \\ Department of Agronomy and Plant Breeding, College of Agriculture, Ferdowsi University of Mashhad, Mashhad, Iran; \\ akbar.aliverdi@stu.um.ac.ir (*correspondingauthor)
}

\begin{abstract}
Crop-rhizobium symbiosis can be influenced by leaching of herbicides which is unavoidable after their application. Due to an adjuvant which might help to develop the low-use-rate of herbicide, an experiment was carried out to compare the impact of the recommended rate (1200 g active ingredient $\left.\mathrm{ha}^{-1}\right)$ and the optimized rate $\left(282.15 \mathrm{~g}\right.$ active ingredient ha $\left.{ }^{-1}\right)$ of pyridate on the biological properties of eight chickpea cultivars inoculated with Mesorbizobium mediterraneum, grown in pots. Based on the required rate of herbicide to give $95 \%$ control of common lambsquarters (Chenopodium album L.) value, the efficacy of pyridate improved up to 3.87 -fold by adding methylated rapeseed oil to spray solution. The 'Desi' cultivar had significantly higher nodulation than 'Kabuli' cultivar. In general, toxicity of the recommended rate was higher than the optimized rate. With the exception of root dry weight, all of the measured parameters were significantly affected by the recommended rate of pyridate in varying degrees. The symbiotic properties of chickpea cultivars were affected more than $10 \%$ at the recommended dose. The reduced nodulation ranged from $29 \%$ to $73 \%$ among cultivars exposed to pyridate at the recommended dose. The 'Desi' cultivar was more sensitive than the 'Kabuli' to the recommended rate of pyridate. We may conclude that effective low-use-rate of pyridate via applying of activator adjuvants should be noted.
\end{abstract}

Keywords: adjuvant, herbicide, Mesorbizobium mediterraneum, nodulation, toxicity

\section{Introduction}

Chickpea, Cicer arietinum L., is the third most important leguminous crop in the world (Mohammadi $e t$ al., 2005). There are two major types of chickpeas, 'Kabuli' and 'Desi'. The former have larger and creamcolored seeds with thin seed coats, while the latter have smaller, dark- or brown-colored seeds with thick seed coats (Gaur et al., 2012). Both types form a highly specific symbiosis with its rhizobial partner, namely Mesorhizobium mediterraneum or Mesorbizobium ciceri (Prevost and Antoun, 2008), that fixes atmospheric nitrogen in exchange for crop carbohydrates (FernaddezAparicio et al., 2009). The amount of fixed nitrogen by $M$. mediterraneum is equivalent to an application of about $150 \mathrm{~N} \mathrm{ha}^{-1}$ in a chickpea crop (Datta et al., 2011); in other words, about $82 \%$ plant-N derives from atmosphere (Unkovich and Pate, 2000). In Iran, therefore, a propensity is being increased to involve legumes as a source of nitrogen in short-term rotation systems with wheat (Mohammadi et al., 2005); above all, the legumes can be a cycle-breaker against graminaceous crop diseases (Malik, 2010).

An open canopy architecture, dwarf stature and slow development are intrinsic plant characteristics of chickpea, decreasing its ability to compete with weeds
(Radicetti et al., 2012). As a result, the tendency of the farmer is to use herbicides to solve this problem because they have helped them to increase yields while reducing labor (Macias et al., 2001). Because less than 5\% of these magic solutions are estimated to reach the target, with the remainder being deposited on the soil (Eerd et al., 2003), the potential environmental and toxicological risks of widespread application of them are highly considered in decreasing the rhizobial growth (Liebman et al., 2004). Later, the phytotoxic effects of quizalafopp-ethyl and clodinafop (Ahemad and Khan, 2010), chlorsulfuron (Anderson et al., 2004), linuron, methabenzthiazuron, and terbutryn (Khan et al., 2006), simazine and prometryn (Kumar et al., 1981), 2,4-D, fluchloralin, and isoproturon (Aamil et al., 2004), fluchloralin and pendimethalin (Pahwa and Prakash, 1992), and isoxaflutole (Datta et al., 2006; 2007; 2008; $2009 ; 2011)$ on chickpea and its symbionts have been reported. Besides, there are reports that symbiotic nitrogen fixation is affected with herbicide application on other pulse crops (Niina, 2008).

In Iran, herbicide pyridate O-(6-chloro-3-phenyl-4pyridazinyl)S-octyl carbonothioateat $1200 \mathrm{~g}$ active ingredient ha $\mathrm{a}^{-1}$ is labeled only for use post-emergence in chickpea to control broadleaf weeds such as common lambsquarters, Chenopodium album L. This is a cosmopolitan summer annual weed (Solymosi and 
Lehoczki, 1989) and a serious constraint to increased production in chickpea in northeast Iran (Sarparast and Sheykh, 2010). In other countries, it is labeled in peanuts, corn, cereals, mint, and rice (Monaco et al., 2002). The herbicidal activity of pyridate (group $6 / \mathrm{C}_{3}$ ) is associated with inhibition of photosynthesis by binding to the quinine B-binding site on the $\mathrm{D}_{1}$ protein of the photosystem II complex in chloroplast thylakoid membranes. This reaction obstructs electron transfer from quinine $\mathrm{A}$ to quinine $\mathrm{B}$ and layoffs carbon dioxide fixation and production of ATP and $\mathrm{NADPH}_{2}$, which are necessary for plant growth (Stein et al., 1984).

From an Integrated Weed Management strategy perspective, it is important to develop the effective lowuse-rate of herbicides (Kudsk, 2008). Hence, it seems that the use of adjuvants is really a suitable manner (Rashed-Mohassel et al., 2009; Aliverdi et al., 2009) so that certain herbicides are sold with a particular adjuvant together in a combi-pack. For instance, in the case of herbicide pinoxaden, the use of methylated rapeseed oil, a methylated rapeseed oil, is essential in order to obtain safe and successful use of this herbicide (Burgis and Harvey, 2012). This adjuvant is also able to improve the efficacy of other herbicides. Rashed-Mohassel et al. (2011) found that the performance of sethoxydim against wild oat (Avena fatua) was increased 1.49-fold in the presence of methylated rapeseed oil. Parsa $e t$ al. (2013) found that the performance of haloxyfop-Pmethyl and imazethapyr against velvetleaf (Abutilon theophrastii) and johnsongrass (Sorghum halepense) were increased 3.49-fold and 2.04-fold, respectively.

So far, not enough data are available on the phytotoxic effects of herbicide pyridate on chickpea $M$. mediterraneum symbiosis. However, based on the available information, the influence of agrochemicals on a pulse crop and its symbionts is depended upon the interactions among the Rhizobium species, crop genotypes and the type and rate of agrochemicals (Ahemad and Khan, 2010). Hence, this research was conducted in two experiments with two objectives of $(i)$ characterizing the rate-response curves of common lambsquarters to pyridate alone and with methylated rapeseed oil to determine the optimized rate; (ii) assessing the effect of the recommended and optimized rates of pyridate on the growth and nodulation of eight chickpea cultivars inoculated with $M$. mediterraneum.

\section{Materials and methods}

\section{Experiment 1: Optimizing rate of herbicide}

The seeds of common lambsquarters were collected from plants in the field near the Research Greenhouse at Ferdowsi University of Mashhad, Iran. Before using the seeds in the experiment, to increase the seed coat permeability of common lambsquarters, they were acidscarified in concentrated sulfuric acid (98\%) for $1 \mathrm{~min}$; and then rinsed with distilled water (Andersen, 1968). Then, the treated seeds were sown in potting trays $(3 \mathrm{~cm}$ inner diameter and $5 \mathrm{~cm}$ in depth) filled with moistened peat. The potting trays were placed in the greenhouse and watered with tap water to prevent moisture stress. The temperature in the greenhouse varied from $18 \pm 4^{\circ} \mathrm{C}$ during the day and $12 \pm 3^{\circ} \mathrm{C}$ at night. When the seedlings were in first leaf stage, they were transplanted to plastic pots $(20 \mathrm{~cm}$ upside diameter and $30 \mathrm{~cm}$ in depth) filled with a mixture of sand, clay loam soil, and peat (1:1:1 by volume). Afterwards, the pots were placed in the greenhouse under the same conditions mentioned above. Pots were irrigated when needed. At two leaf stage, the seedlings were thinned to four per pot. At the three leaf stage, the treatments were exerted using an overhead trolley sprayer (Matabi 121030 Super Agro 20 L sprayer; Agratech Services-Crop Spraying Equipment, Rossendale, UK) equipped with an 8002 flat fan nozzle calibrated to deliver $200 \mathrm{~L} \mathrm{ha}^{-1}$ at 2 bar spray pressure.

The treatments were consisted of herbicide pyridate at $0,75,150,300,600$, and $1200 \mathrm{~g}$ active ingredient $\mathrm{ha}^{-1}$ $\left(600 \mathrm{~g}\right.$ pyridate $\left.\mathrm{L}^{-1}\right)$ alone and with methylated rapeseed oil (47\% methylated rapeseed oil) at $0.5 \%(\mathrm{v} / \mathrm{v})$, according to the label, against common lambsquarters. The applied rates were $0 \%, 6 \%, 12 \%, 25 \%, 50 \%$, and $100 \%$ of the labeled rate for Iran. Four weeks after spraying, the biomass of experimental units was harvested fresh and dry weight was determined after the fresh samples were oven-dried at $75^{\circ} \mathrm{C}$ for $48 \mathrm{~h}$. The response of fresh and dry weight to herbicide rate was assumed by a log-logistic model that was already described by Streibig et al. (1993) and Tind et al. (2009). On the basis of the nonlinear regression parameters, using logistic doseresponse model of $\mathrm{Y}=\mathrm{C}+\{\mathrm{D}-\mathrm{C} / 1+\exp [\mathrm{b}(\log \mathrm{X}-$ $\log E D)]\}$; where $\mathrm{Y}$ is the response (e.g., dry weight), $\mathrm{C}$ is the lower limit, $\mathrm{D}$ is the upper limit corresponding to the response of the untreated control, $b$ is the slope of the line, the $\mathrm{ED}_{50}$ and $\mathrm{ED}_{95}$ values were calculated, denoting the required rate of pyridate to give $50 \%$ and $95 \%$ control, respectively. The required rate of pyridate along with methylated rapeseed oil in which $95 \%$ control was obtained, was chosen as optimized rate in subsequent experiment.

\section{Experiment 2: Comparing effect of rates}

The chickpea cultivars seeds were obtained from the Seed Bank of Research Department of Plant Science, Ferdowsi University of Mashhad, Iran. Before using the seeds in the experiment, each of ten chickpea cultivars seeds were disinfected with sodium hypo chloride (5\%) for a period of $5 \mathrm{~min}$, and then dried with paper towels after washing with distilled water. Before planting, the seeds were dipped for a period of 1 hour into a suspension $M$. mediterraneum (obtained from the Mehre-Asia Biotechnology Co., Tehran, Iran) at a rate of $12 \mathrm{~g}$ inoculants per $1 \mathrm{~kg}$ seeds according to label. Ten seeds inoculated of each chickpea cultivar were grown in plastic pot $(35 \mathrm{~cm}$ inner diameter and $50 \mathrm{~cm}$ in depth) at $1 \mathrm{~cm}$ depth that was filled with an autoclaved mixture of loam soil and sand (1:10 by volume). The seedlings were thinned to three per pot at the one-leaf stage. When chickpea cultivars were in third leaf stage, they were sprayed as already described above. The experiment was set up as a completely randomized design with $8 \times 3$ factorial combinations: the eight chickpea cultivars obtained from Mashhad Chickpea Collection (six 'Kabuli' types (K-MCC-252, K-MCC-283, K-MCC358, K-MCC-360, K-MCC-395, and K-MCC-950) and two 'Desi' types (D-MCC-49 and D-MCC-362)) and 
94

three herbicide rates (control, the recommended rate (1200 $\mathrm{g}$ active ingredient $\mathrm{ha}^{-1}$ ) and the optimized rate $\left(282.15 \mathrm{~g}\right.$ active ingredient $\left.\mathrm{ha}^{-1}\right)$. There were three replications. The treatments were applied at two leaf stage using the method mentioned above.

The biomass of experimental units was harvested at thirty days after herbicide treatment. At harvest time, growth parameters (shoot and root dry weights); nodulation (nodule number, nodule dry weight and nodule largest diameter); amount of $\mathrm{N}$ (shoot $\mathrm{N}$, root $\mathrm{N}$ ) and amount of phosphorus (shoot phosphorus, root phosphorus) were measured. Plant shoots were harvested at ground level and roots were then hand washed. The numbers of nodules per plant were counted after careful hand-washing of the roots. Dry weights of nodules, shoots and roots were determined as already described above. Phosphorus and nitrogen content in roots and shoots were determined at thirty days after harvest using the method of Jackson (1967) and micro-Kjeldahl (Iswaran and Marwah, 1980), respectively. This trial was repeated. Since similar results were nearly detected in both studies, data were averaged across the two trials and analyzed in accordance with the first experiment. At all measurements, the data were changed to individual plant and subjected to analyze of variance using the SAS software.

\section{Results and Discussion}

\section{Experiment 1}

Dose-response curves of common lambsquarters treated with pyridate alone or in the presence of the methylated rapeseed oil are showed in Fig. 1. The $\mathrm{ED}_{50}$ and $\mathrm{ED}_{95}$ values based on the fresh weight of common lambsquarters for pyridate were 226.29 and $970.94 \mathrm{~g}$ active ingredient of pyridate $\mathrm{ha}^{-1}$, respectively. Whereas, these values based on the dry weight were 192.85 and $1092.02 \mathrm{~g}$ active ingredient of pyridate $\mathrm{ha}^{-1}$, respectively. As judged by the $\mathrm{ED}_{50}$ and $\mathrm{ED}_{95}$ values given in $\mathrm{Tab} .1$, the addition of the methylated rapeseed oil decreased both values significantly, indicating an increase in the efficacy of pyridate to control common lambsquarters. As according to dry weight, the $\mathrm{ED}_{95}$ value for pyridate was decreased 3.87-fold by adding this adjuvant. Rashed-Mohassel et al. (2011) and Parsa et al. (2013) asserted that the methylated rapeseed oil was able to enhance the activity of some herbicides. Generally, it is widely believed that the benefit of an oil adjuvant can be related to their ability (i) to increase the drying period of the spray droplets during their fly time before impacting the leaves, (ii) to prevent bouncing off after impacting the leaves, (iii) to decrease contact angle of the droplet on the leaf surface and improve the spreading of them on the leaf surface, (iv) to delay crystallization of the active ingredient on the leaf surface, $(v)$ to reduce the volatization and photo-decomposition period of the active ingredient, (vi) to act as a penetrant agent on the leaf epicuticular wax, and mainly (vii) to enhance the penetrability of the active ingredient into the plants (Rashed-Mohassel et al., 2010; 2011; Izadi-Darbandi et al., 2013).

The rate of $282.15 \mathrm{~g}$ active ingredient of pyridate $\mathrm{ha}^{-1}$ was chosen as the optimized rate to compare with the recommended rate (1200 g active ingredient of pyridate ha $\left.{ }^{1}\right)$ in the further experiment.
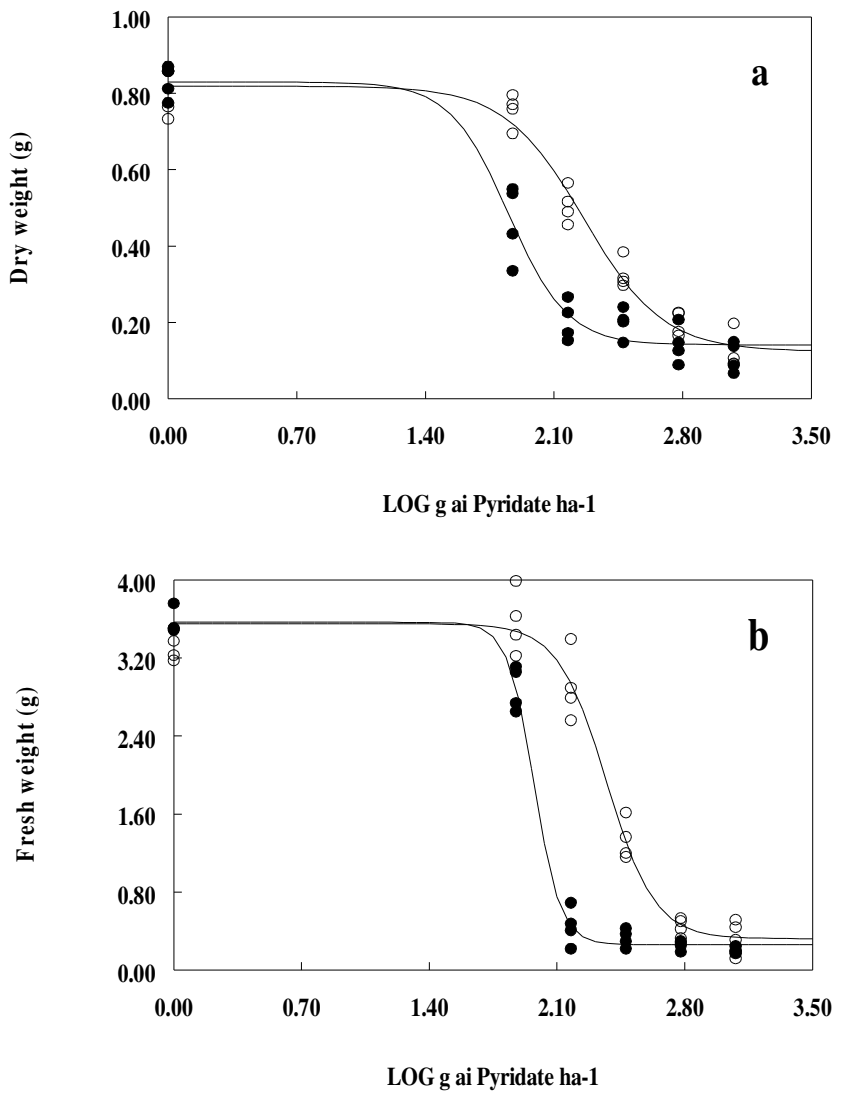

Fig. 1. Dose-response curves for herbicide pyridate alone $(\bigcirc)$ and in the presence of methylated rapeseed oil $(\mathbf{O})$ against common lambsquarters. The lines were fitted on data belong to shoot dry weight (a) and shoot fresh weight (b).

\section{Experiment 2}

Rhizobial colonization of chickpea roots was observed in all experimental units. Generally, the analysis of variance revealed (Tab. 2) that with the exception of root dry weight; the shoot dry weight, number of nodules, nodules dry weight, shoot $\mathrm{N}$, root $\mathrm{N}$, shoot $\mathrm{P}$, and root $\mathrm{P}$ per plant were affected significantly by the treatment factor in varying degree. All of the measured parameters were significantly affected by the cultivar factor. Moreover, with the exception of root P per plant, the interaction between cultivar and treatment were significant in all of the measured parameters.

Based on shoot dry weight, the 'Desi' cultivars (DMCC-49 and D-MCC-362) grew heavier than the 'Kabuli' cultivars (Tab. 2). The recommended and optimized rates of pyridate had no effect on the shoot dry weight of K-MCC-252 cultivar. In other 'Kabuli' cultivars (K-MCC-283, K-MCC-358, K-MCC-360, KMCC-395, and K-MCC-950), a significant reduction in the shoot dry weight was observed with application of the recommended rate of pyridate. The decrease was about $37 \%, 41 \%, 44 \%, 35 \%$, and $49 \%$, respectively. In the 'Desi' cultivars, this parameter was significantly reduced by both the recommended rate and the optimized rates of pyridate. The decrease was about $53 \%$ and $55 \%$ for the recommended rate in D-MCC-49 cultivar and 35\% and 
Tab. 1. Estimated regression parameters for the dose-response curves (in Fig. 1) of common lambsquarters (Chenopodium album L.) treated with herbicide pyridate alone and in the presence of methylated rapeseed oil at $0.5 \%$ concentration of spray volume

\begin{tabular}{|c|c|c|c|c|c|}
\hline \multirow{3}{*}{ Treatment } & \multicolumn{5}{|c|}{ Shoot fresh weigh } \\
\hline & $b$ & $C$ & $D$ & $E D_{50}$ & $E D_{95}$ \\
\hline & & $\left(\right.$ g plant $\left.^{-1}\right)$ & $\left(\right.$ g plant $\left.^{-1}\right)$ & \multicolumn{2}{|c|}{ ( $\mathrm{g}$ active ingredient $\mathrm{ha}^{-1}$ ) } \\
\hline Pyridate & $7.54(1.55)$ & $3.49(0.11)$ & $0.32(0.12)$ & $226.29(11.70)$ & $970.94(10.22)$ \\
\hline \multirow[t]{2}{*}{ Pyridate + methylated rapeseed oil } & $13.79(1.21)$ & $3.56(0.06)$ & $0.25(0.04)$ & $96.14(6.29)$ & $207.34(7.81)$ \\
\hline & \multicolumn{5}{|c|}{ Shoot dry weight } \\
\hline Pyridate & $4.64(0.75)$ & $0.16(0.02)$ & $0.81(0.02)$ & $192.85(10.50)$ & $192.85(10.50)$ \\
\hline Pyridate + methylated rapeseed oil & $6.28(1.85)$ & $0.12(0.02)$ & $0.83(0.03)$ & $82.39(9.51)$ & $82.39(9.51)$ \\
\hline
\end{tabular}

* The concentration that was chosen as the optimized rate. The standard errors are in parentheses $(\mathrm{p}=0.05)$. The parameter of $\mathrm{b}$ is the slope of the line, $\mathrm{C}$ is the lower limit, $\mathrm{D}$ is the upper limit corresponding to the response of the untreated control, and ED 50 or ED 95 is the required rate of herbicide to give $50 \%$ or $95 \%$ control.

Tab. 2. Effect of the recommended and optimized rates of pyridate on biological properties of the chickpea cultivars inoculated with $M$. mediterraneum

\begin{tabular}{|c|c|c|c|c|c|c|c|c|c|}
\hline \multirow[b]{2}{*}{ Cultivar } & \multirow[b]{2}{*}{ Treatment } & \multicolumn{2}{|c|}{ Dry weight } & \multicolumn{2}{|c|}{ Nodulation } & \multicolumn{2}{|c|}{ Nitrogen content } & \multicolumn{2}{|c|}{ Phosphorus content } \\
\hline & & $\begin{array}{c}\text { Shoot } \\
\text { (g/plant) }\end{array}$ & $\begin{array}{c}\text { Root } \\
\text { (g/plant) }\end{array}$ & $\begin{array}{c}\text { Number } \\
\text { (no./plant) }\end{array}$ & $\begin{array}{l}\text { Dry weight } \\
\text { (mlg/plant) }\end{array}$ & $\begin{array}{l}\text { Shoot } \\
(\mathrm{mg} / \mathrm{g})\end{array}$ & $\begin{array}{l}\text { Root } \\
(\mathrm{mg} / \mathrm{g})\end{array}$ & $\begin{array}{l}\text { Shoot } \\
(\mathrm{mg} / \mathrm{g})\end{array}$ & $\begin{array}{c}\text { Root } \\
(\mathrm{mg} / \mathrm{g})\end{array}$ \\
\hline \multirow[t]{3}{*}{ K-MCC-252 } & Control & $0.98^{\text {ef }}$ & $0.30 \mathrm{e}-\mathrm{g}$ & $37^{\mathrm{cd}}$ & $89^{c}$ & $26^{\mathrm{f}-\mathrm{i}}$ & $17 \mathrm{~g}^{-\mathrm{i}}$ & $0.20^{\text {gh }}$ & $0.12^{\text {gh }}$ \\
\hline & The recommended rate & $0.92^{\mathrm{fg}}$ & $0.35^{\mathrm{b}}$ & $26^{\mathrm{ef}}$ & $52^{\mathrm{e}}$ & $19^{j-1}$ & $9^{\mathrm{k}-\mathrm{m}}$ & $0.11^{1}$ & $0.07^{\mathrm{ij}}$ \\
\hline & The optimized rate & $1.02 \mathrm{df}$ & $0.28 \mathrm{~g}^{\mathrm{h}}$ & $40^{b-d}$ & $93^{b c}$ & $23^{h-j}$ & $14^{\mathrm{i}-\mathrm{k}}$ & $0.20^{\text {gh }}$ & $0.14 \mathrm{f}^{\mathrm{h}}$ \\
\hline \multirow[t]{3}{*}{ K-MCC-283 } & Control & $1.21^{\mathrm{bc}}$ & $0.31^{\mathrm{c}-\mathrm{g}}$ & $49^{a b}$ & $89^{\mathrm{c}}$ & $34^{b-d}$ & $27^{\mathrm{cd}}$ & $0.23^{\mathrm{d}-\mathrm{g}}$ & $0.16^{\mathrm{c}-\mathrm{g}}$ \\
\hline & The recommended rate & $0.76^{\mathrm{gi}}$ & $0.29^{\text {gh }}$ & $22^{\mathrm{fg}}$ & $45^{\text {ef }}$ & $17^{\operatorname{lm}}$ & $7^{\mathrm{m}}$ & $0.15 \mathrm{i}^{\mathrm{j}}$ & $0.10^{\mathrm{hi}}$ \\
\hline & The optimized rate & $1.22^{b c}$ & $0.36^{\mathrm{b}}$ & $41^{b-d}$ & $90^{\mathrm{bc}}$ & $30^{\mathrm{d}-\mathrm{f}}$ & $22^{d-g}$ & $0.26 \mathrm{a}^{-\mathrm{c}}$ & $0.19^{\mathrm{a}-\mathrm{e}}$ \\
\hline \multirow[t]{3}{*}{ K-MCC-358 } & Control & $1.28^{\mathrm{ac}}$ & $0.36^{b}$ & $33^{\mathrm{de}}$ & $83^{\mathrm{cd}}$ & $22 i^{-k}$ & $13^{\mathrm{i}-\mathrm{k}}$ & $0.21^{\mathrm{fg}}$ & $0.15 \mathrm{~d}^{\mathrm{g}}$ \\
\hline & The recommended rate & $0.75^{\text {hi }}$ & $0.33^{\mathrm{b}-\mathrm{d}}$ & $16^{\mathrm{g}}$ & $34^{\mathrm{f}}$ & $18^{\mathrm{k}-\mathrm{m}}$ & $8^{\mathrm{k}-\mathrm{m}}$ & $0.12^{\mathrm{kl}}$ & $0.05^{j}$ \\
\hline & The optimized rate & $1.19^{\mathrm{bc}}$ & $0.33^{b-d}$ & $49^{\mathrm{ab}}$ & $92^{b c}$ & $19^{\mathrm{j}-1}$ & $10^{\mathrm{j}-\mathrm{m}}$ & $0.18^{\mathrm{h}}$ & $0.12^{\text {gh }}$ \\
\hline \multirow[t]{3}{*}{ K-MCC-360 } & Control & $1.18^{\mathrm{bd}}$ & $0.24^{\mathrm{i}}$ & $40^{b-d}$ & $88^{\mathrm{cd}}$ & $28^{\mathrm{e}-\mathrm{g}}$ & $20^{\mathrm{d}-\mathrm{g}}$ & $0.25^{\mathrm{c}-\mathrm{e}}$ & $0.19^{\mathrm{a}-\mathrm{e}}$ \\
\hline & The recommended rate & $0.66^{\mathrm{i}}$ & $0.34^{\mathrm{b}-\mathrm{d}}$ & $15^{\mathrm{g}}$ & $56^{\mathrm{e}}$ & $18^{\mathrm{k}-\mathrm{m}}$ & $8^{\mathrm{k}-\mathrm{m}}$ & $0.12^{\mathrm{kl}}$ & $0.10^{\mathrm{hi}}$ \\
\hline & The optimized rate & $1.02 \mathrm{df}$ & $0.30 \mathrm{e}-\mathrm{g}$ & $47^{a-c}$ & $80^{\mathrm{cd}}$ & $27^{\mathrm{f}-\mathrm{h}}$ & $18^{\mathrm{f}-\mathrm{i}}$ & $0.27^{\mathrm{a}-\mathrm{c}}$ & $0.20^{\mathrm{a-c}}$ \\
\hline \multirow[t]{3}{*}{ K-MCC-395 } & Control & $1.16^{\text {bd }}$ & $0.31^{\mathrm{c}-\mathrm{g}}$ & $42^{b-d}$ & $82^{\mathrm{cd}}$ & $33^{b-d}$ & $25^{\mathrm{ce}}$ & $0.22^{\mathrm{e}-\mathrm{g}}$ & $0.15^{\mathrm{d}-\mathrm{g}}$ \\
\hline & The recommended rate & $0.75^{\text {hi }}$ & $0.30^{\mathrm{e}-\mathrm{g}}$ & $17^{\mathrm{fg}}$ & $53^{\mathrm{e}}$ & $15^{\operatorname{lm}}$ & $5^{m}$ & $0.11^{1}$ & $0.04 \mathrm{j}$ \\
\hline & The optimized rate & $1.13^{\mathrm{ce}}$ & $0.28^{\text {gh }}$ & $39^{\mathrm{cd}}$ & $82^{\mathrm{cd}}$ & $32^{\mathrm{ce}}$ & $23^{d-f}$ & $0.21^{\mathrm{fg}}$ & $0.14 \mathrm{f}-\mathrm{h}$ \\
\hline \multirow[t]{3}{*}{ K-MCC-950 } & Control & $1.31^{\mathrm{f}}$ & $0.29^{\text {gh }}$ & $43^{b-d}$ & $88^{\mathrm{cd}}$ & $23^{h-j}$ & $15^{\mathrm{h}-\mathrm{j}}$ & $0.26^{\mathrm{a}-\mathrm{c}}$ & 0.19 a-e \\
\hline & The recommended rate & $0.67^{\mathrm{i}}$ & $0.28^{\text {gh }}$ & $17^{\mathrm{fg}}$ & $45^{\text {ef }}$ & $18^{\mathrm{k}-\mathrm{m}}$ & $8^{\mathrm{k}-\mathrm{m}}$ & $0.11^{1}$ & $0.12 \mathrm{gh}$ \\
\hline & The optimized rate & $1.05^{\mathrm{df}}$ & $0.29^{\text {gh }}$ & $42^{b-d}$ & $81^{\mathrm{cd}}$ & $25^{\mathrm{g}-\mathrm{i}}$ & $16^{\text {hi }}$ & $0.24^{\mathrm{c}-\mathrm{f}}$ & $0.17 \mathrm{~b}-\mathrm{f}$ \\
\hline \multirow[t]{3}{*}{ D-MCC-49 } & Control & $1.42^{a}$ & $0.35^{b}$ & $57^{a}$ & $104^{\mathrm{ab}}$ & $35^{b c}$ & $29^{b}$ & $0.29^{\mathrm{a}}$ & $0.21 \mathrm{ab}$ \\
\hline & The recommended rate & $0.66^{\mathrm{i}}$ & $0.34^{\mathrm{b}-\mathrm{d}}$ & $21^{\mathrm{fg}}$ & $38^{\mathrm{f}}$ & $16^{\mathrm{lm}}$ & $6^{\mathrm{m}}$ & $0.14^{\mathrm{jk}}$ & $0.12 \mathrm{gh}$ \\
\hline & The optimized rate & $0.92^{\mathrm{fg}}$ & $0.26^{\text {hi }}$ & $54^{a}$ & $103^{\mathrm{ab}}$ & $37^{b}$ & $29^{b}$ & $0.26^{\mathrm{a-c}}$ & 0.19 a-e \\
\hline \multirow[t]{3}{*}{ D-MCC-362 } & Control & $1.40^{\mathrm{a}}$ & $0.39^{\mathrm{ab}}$ & $56^{a}$ & $106^{\mathrm{a}}$ & $43^{a}$ & $35^{a}$ & $0.26^{\mathrm{a}-\mathrm{c}}$ & 0.19 a-e \\
\hline & The recommended rate & $0.63^{i}$ & $0.33^{b f}$ & $15^{\mathrm{g}}$ & $44^{\text {ef }}$ & $14^{\mathrm{m}}$ & $4 \mathrm{~m}$ & $0.14^{\mathrm{jk}}$ & $0.10 \mathrm{hi}$ \\
\hline & The optimized rate & $0.87 \mathrm{f}^{\mathrm{h}}$ & $0.42^{\mathrm{a}}$ & $48^{\mathrm{ab}}$ & $112^{a}$ & $42^{a}$ & $35^{\mathrm{a}}$ & $0.29^{a}$ & $0.22 \mathrm{a}$ \\
\hline \multicolumn{2}{|c|}{ LSD Treatment $(d f=2)$} & $0.06^{\prime \prime}$ & $0.01^{\mathrm{ns}}$ & $3.32^{* *}$ & $4.84^{* * *}$ & $1.46^{* *}$ & $1.96^{* *}$ & $0.01^{*}$ & $0.01^{*}$ \\
\hline \multicolumn{2}{|c|}{ LSD Cultivar $(d f=7)$} & $0.09^{*}$ & $0.02^{* *}$ & $5.42^{*}$ & $7.90^{*}$ & $2.38^{\cdots *}$ & $3.20^{*}$ & $0.02^{*}$ & $0.02^{*}$ \\
\hline \multicolumn{2}{|c|}{ LSD Treatment $\times$ Cultivar $(d f=14)$} & $0.17^{* *}$ & $0.03^{* *}$ & $9.40^{* *}$ & $13.69^{* *}$ & $4.13^{* *}$ & $5.55^{*}$ & $0.03^{* *}$ & $0.04^{\text {ns }}$ \\
\hline
\end{tabular}

K- and D- is abbreviation of 'Kabuli' and 'Desi' cultivars, respectively. Mashhad Chickpea Collection is shorted to MCC. df is degree of freedom. The recommended rate was $1200 \mathrm{~g}$ active ingredient of pyridate $\mathrm{ha}^{-1}$ and the optimized rate was $282.15 \mathrm{~g}$ active ingredient of pyridate ha $\mathrm{a}^{-1}+$ methylated rapeseed oil at $0.5 \%$ concentration of spray volume. Means in a column followed by same letter are not significantly different at the 0.05 probability level determined by Least Significant Difference Test (LSD). *: Statistical significance $(\mathrm{p} \leq 0.05) ;{ }^{* *}$ : Highly statistical significant $(\mathrm{p} \leq 0.01) ;{ }^{* * *}$ : Very highly statistical significant $(\mathrm{p} \leq 0.001) ;{ }^{\text {ns: }}$ No statistical significant. 
96

$38 \%$ for the optimized rate in D-MCC-362 cultivar, respectively. The highest root dry weight and the lowest root dry weight were observed in D-MCC-362 and KMCC-360 cultivars, respectively (Tab. 2). Although the application of the recommended rate on K-MCC-252 and K-MCC-360 cultivars led to stimulation in root dry weight, both treatments had no significant effect on the root dry weight in other cultivars. Generally, the results revealed that the shoot:root ratio from plants treated with herbicide was slightly lower relative to control (data not shown). It is established that many pesticides induce a reduction in biological $\mathrm{N}_{2}$ fixation via their noxious effect on rhizobial bacteria (Liebman et al., 2004); as a result, any factor which unfits growing conditions results in a reduced shoot:root ratio (Harris, 1992); that is, root grows more in weight than shoot. Similar results have also been reported (Niina, 2008).

Between two types of chickpea, the 'Desi' cultivars (D-MCC-49 and D-MCC-362) had higher nodulation (nodule number and dry weight) than the 'Kabuli' cultivars (Tab. 2). In all chickpea cultivars, the number of nodules per plant was significantly decreased by applying the recommended rate of pyridate. This parameter was found to be reduced by about $29 \%, 51 \%, 51 \%, 62 \%, 59 \%$, $60 \%, 63 \%$, and $73 \%$ in K-MCC-252, K-MCC-283, KMCC-358, K-MCC-360, K-MCC-395, K-MCC-950, D-MCC-49, and D-MCC-362 cultivars exposed to pyridate at the recommended dose, respectively. There was a similar trend for the dry weight of nodules per plant (Tab. 2). The application of pyridate at the recommended dose reduced significantly by about $41 \%$, $49 \%, 59 \%, 36 \%, 34 \%, 48 \%, 63 \%$, and $58 \%$ as compared with the control, respectively. The number and the dry weight of nodules per plant were significantly unaffected with the optimized rate in all cultivars. The decrease in both nodule number and dry weight in this experiment indicates that symbiosis breaks down at the early stages of symbiosis establishment. The result obtained in this study indicates that shoot $\mathrm{N}$ was more than root $\mathrm{N}$ in all chickpea cultivars (Tab. 2). The shoot $\mathrm{N}$ of all chickpea cultivars was generally affected by the recommended dose of pyridate, but in K-MCC-358 cultivar; it was not statistically significant. The optimized rate of pyridate had no effect on the shoot $\mathrm{N}$ content of all cultivars. A similar trend for the root $\mathrm{N}$, shoot $\mathrm{P}$, and root $\mathrm{P}$ was also observed. As can be observed (Tab. 2), when pyridate was used at the recommended dose, these parameters were decreased as compared with both control and the optimized dose of pyridate.

Although the effect of pyridate on chickpea - $M$. mediterraneum symbiosis was not found in the literature, the reduced nodulation by some herbicides, especially the photosystem II- inhibiting herbicides, in chickpea have already reported as listed above. The literature review indicated that legume-symbionts symbiosis may directly and indirectly affected by herbicides via (1) altering the balance of leacetic acid in host plant, leading to lower root nodulation (Kremer and Means, 2009); (2) reducing root biomass, leading to limit the number of available sites for rhizobia to attach to root hairs (Anderson et al., 2004); (3) altering carbohydrate preparation to the root nodules; (4) altering the activity of a critical enzyme in the root nodules, called nitrogenase (Niewiadomska and Sawicka, 2002); (5) inhibiting or inactivating the biochemical signaling by either symbionts or plants required to initiate nodule development (Ahemad and Khan, 2011); and/or (6) reducing the capacity of cell division, leading to inhibit nodule development (Datta $e t$ al., 2009).

\section{Conclusion}

In this study, we demonstrated the deleterious effects of pyridate on chickpea - M. mediterraneum symbiosis. Generally, the 'Desi' cultivars were more sensitive than the 'Kabuli' cultivars to pyridate application. In our study, several symbiotic properties of chickpea cultivars were affected more than $10 \%$ at the recommended dose. Because chickpea - M. mediterraneum symbiosis was not affected by the optimized dose of pyridate, thus, we may conclude that: effective low-use-rate should be noted; the application of activator adjuvants can be a suitable manner to decrease unfavorable effects of herbicides; because a higher leaching of herbicide is imaginable in light texture soils, the intensive application of herbicide should be avoided as much as possible; leaching of herbicide should be minimized by some adjuvants.

\section{Acknowledgments}

This work was supported by a grant from the College of Agriculture, Ferdowsi University of Mashhad, Iran through the RESEARCH program (Project No. 2/20237). The rhizobium was provided by Mehr-e-Asia Biotechnology Co., Tehran, Iran. Hereby, it is acknowledged.

\section{References}

Aamil M, Zaidi A, Khan MS (2004). Effect of herbicides on growth, nodulation and yield of chickpea (Cicer arietinum L.). Ann Plant Protect Sci 12:123-127.

Ahemad M, Khan MS (2010). Ameliorative effects of Mesorbizobium sp. MRC4 on chickpea yield and yield components under different rates of herbicide stress. Pestic Biochem Phys 98:183-190.

Ahemad M, Khan MS (2011). Response of greengram [Vigna radiate (L.) Wilczek] grown in herbicide-amended soil to inoculation with Bradyrhizobium sp. (vigna) MRM6. J Agr Sci Tech 13:1209-1222.

Aliverdi A, Rashed-Mohassel MH, Zand E, Nassiri-Mahallati M (2009). Increased foliar activity of clodinafoppropargyl and/or tribenuron-methyl by surfactants and their synergistic action on wild oat (Avena ludoviciana) and wild mustard (Sinapis arvensis). Weed Bio Manag 9:292-299.

Andersen RN (1968). Germination and establishment of weeds for experimental purposes. Weed Science Society of America, Urbana, IL, USA.

Anderson A, Baldock JA, Rogers SL, Bellotti W, Gill G (2004). Influence of chlorsulfuron on rhizobial growth, nodule formation, and nitrogen fixation with chickpea. Aust J Agr Res 55:1059-1070. 
Burgis M, Harvey J (2012). Adjuvants - Oils, surfactants and other additives for farm chemicals. Grains Research and Development Corporation. Australia.

Datta A, Sindel BM, Jessop RS, Birchall C, Felton WL (2006). Differential response of chickpea genotypes to isoxaflutole. Commun. Agric Appl Biol Sci 71:733-742.

Datta A, Sindel BM, Jessop RS, Kristiansen P, Felton W.L (2007). Phytotoxic response and yield of chickpea (Cicer arietinum) genotypes with pre-emergence application of isoxaflutole. Aust J Exp Agr 47:1460-1467.

Datta A, Sindel BM, Kristiansen P, Jessop RS, Felton WL (2008). The effect of soil $\mathrm{pH}$ on chickpea (Cicer arietinum) genotype sensitivity to isoxaflutole. Plant Soil 303:49-54.

Datta A, Sindel BM, Kristiansen P, Jessop RS, Felton WL (2009). Effect of isoxaflutole on the growth, nodulation and nitrogen fixation of chickpea (Cicer arietinum L.). Crop Prot 28:923927.

Datta A, Sindel BM, Kristiansen P, Birchall C, Jessop RS, Felton WL (2011). Influence of nitrogen fertilization and isoxaflutole on the nodulation of chickpea (Cicer arietinum). Weed Bio Manag 11:91-99.

Eerd LLV, Hoagland RE, Zablotowicz RM, Hall JC (2003). Pesticide metabolism in plants and microorganisms. Weed Sci 51:472-495.

Fernaddez-Aparicio M, Rispail N, Prats E, Morandi D, GarciaGarrido JM, Dumas-Gaudot E et al. (2009). Parasitic plant infection is partially controlled through symbiotic pathways. Weed Res 50:76-82.

Gaur PM, Srinivasan S, Suresh K, Deepika SR, Rao BV (2012). Inheritance of Natural seed-coat cracking in chickpea. J Hered 103:898-902.

Harris RW (1992). Root-shoot ratios. J Arboric 18:39-42.

Iswaran V, Marwah TS (1980). A modified rapid Kjeldahl method for determination of total nitrogen in agricultural and biological materials. Geobios 7:281-282.

Izadi-Darbandi E, Aliverdi A, Hammami H (2013). Behavior of vegetable oils in relation to their influence on herbicides' effectiveness. Ind Crop Prod 44:712-717.

Jackson ML (1967). Soil chemical analysis. New Delhi, India.

Khan MS, Zaidi A, Rizvi PQ (2006). Biotoxic effects of herbicides on growth, nodulation, nitrogenase activity, and seed production in chickpeas. Commun Soil Sci Plant 37:17831793.

Kremer RJ, Means NE (2009). Glyphosate and glyphosate-resistant crop interactions with rhizosphere microorganisms. Eur J Agron 31:153-161.

Kudsk P (2008). Optimising herbicide rate: a straightforward approach to reduce the risk of side effects of herbicides. Environmentalist 28:49-55.

Kumar S, Pahwa SK, Promila K, Sharma HR (1981). Effect of simazine and prometryne on the growth and nodulation of chickpea (Cicer arietinum L.). J Agr Sci 97:663-668.

Liebman M, Mohler CL, Staver CP (2004). Weed management: a need for ecological approaches. In: Ecological Management of
Agricultural Weeds. 8-18 p. Cambridge University Press. UK. Macias FA, Molinillo JMG, Galindo JCG, Varela RM, Simonet AM, Castellano D (2001). The use of allelopathic studies in the search for natural herbicides. J Crop Product 4:237-255.

Malik R (2010). Soil quality benefits of break crops and/ or crop rotations-a review. $19^{\text {th }}$ world congress of soil science, soil solutions for a changing world. Brisbane, Australia. 95-98.

Mohammadi G, Javanshir A, Khooie FR, Mohammadi SA, Salmasi SZ (2005). Critical period of weed interference in chickpea. Weed Res 45:57-63.

Monaco TJ, Weller SC, Ashton FM (2002). Weed science: principles and practices. $3^{\text {rd }}$ ed. John Wiley and Sons, Inc., New York. USA.

Niewiadomska A, Sawicka A (2002). Effect of carbendazim, imazetapir and thiram on nitrogenase activity, number of microorganisms in soil and yield of hybrid lucerne (Medicago media). Pol J Environ Stud 11:737-744.

Niina K (2008). Influence of residual flucarbazone-sodium on inoculation success measured by growth parameters, nitrogen fixation, and nodule occupancy of field pea. Ms.C. Thesis. University of Saskatchewan. Saskatoon. Canada.

Pahwa SK, Prakash J (1992). Effect of some herbicides on the growth, nodulation and $\mathrm{N}_{2}$ fixation in chickpea (Cicer arietinum L.). Indian J Plant Physi 35:207-212.

Parsa M, Aliverdi A, Hammami H (2013). Effect of the recommended and optimized doses of haloxyfop-P-methyl or imazethapyr on soybean-Bradyrbizobium japonicum symbiosis. Ind Crop Prod 50:197-202.

Prevost D, Antoun H (2008). Root nodule bacteria and symbiotic nitrogen fixation. In: Soil sampling and methods of analysis. $2^{\text {nd }}$ Ed. (Carter MR, Gregorich EG) Taylor \& Francis Group, LLC.

Radicetti E, Mancinelli R, Campiglia E (2012). The competitive ability of different chickpea (Cicer arietinum) genotypes against Polygonum aviculare under field conditions. Crop Prot 42:312-319.

Rashed-Mohassel MH, Aliverdi A, Ghorbani R (2009). Effects of a magnetic field and adjuvant in the efficacy of cycloxydim and clodinafop-propargyl on the control of wild oat (Avena fatua). Weed Bio Manag 9:300-306.

Rashed-Mohassel MH, Aliverdi A, Hammami H, Zand E (2010). Optimizing the performance of diclofop-methyl, cycloxydim, and clodinafop-propargyl on littleseed canarygrass (Phalaris minor) and wild oat (Avena ludoviciana) control with adjuvants. Weed Bio Manag 10:57-63.

Rashed-Mohassel MH, Aliverdi A, Rahimi S (2011). Optimizing dosage of sethoxydim and fenoxaprop-p-ethyl with adjuvants to control wild oat. Ind Crop Prod 34:1583-1587.

Sarparast R, Sheykh F (2010). Effect of different herbicides on weed control in chickpea (Cicer arietinum L.). Iranian J Pulse Res 1:33-42. (Abstract in English). 
Solymosi P, Lehoczki E (1989). Characterization of a triple (atrazine-pyrazon-pyridate) resistant biotype of common lambsquarters (Chenopodium album L.). J Plant Physiol 134:685-690.

Stein RR, Castellvi AL, Bogacz JP, Wraight CA (1984). Herbicidequinone competition in the acceptor complex of photosynthetic reaction centers from Rhodopseudomonas sphaeroides: a bacterial model for PS-II-herbicide activity in plants. J Cell Biochem 24:243-59.Streibig JC, Rudemo M, Jensen JE (1993). Doseresponse models. In: Herbicide Bioassay (ed. by Streibig JC, Kudsk P). CRC Press, Boca Raton, FL, 29-55.
Tind T, Mathiesen TJ, Jensen JE, Ritz C, Streibig JC (2009). Using a selectivity index to evaluate logarithmic spraying in grass seed crops. Pest Manage Sci 65:1257-1262.

Unkovich MJ, Pate JS (2000). An appraisal of recent field measurements of symbiotic $\mathrm{N}_{2}$ fixation by annual legumes. Field Crop Res 65:211-228.

Zand E, Baghestani MA, Shimi P, Phaghih A (2007). Analysis of herbicides management in Iran. A Report for Agricultural Research and Education Organization, Ministry of Jihad-e-Agriculture, Tehran. 